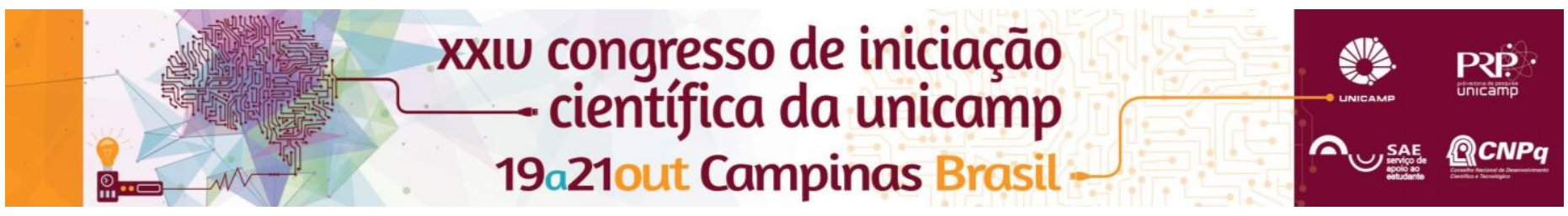

\title{
Raça e axé: um estudo sobre as relações raciais nos terreiros de Candomblé de Campinas
}

\author{
Homero Dantas Ragnane
}

\section{Resumo}

O objetivo principal deste trabalho é realizar um estudo exploratório-comparativo a respeito da forma como se dão as relações raciais em terreiros de Candomblé instalados nos municípios de Campinas. É interessante analisar e investigar a predominância de adeptos brancos no Candomblé campineiro, bem como observar se esse fato altera (e se sim, como) a organização e referências religiosas da construção do candomblé no contexto de Campinas.

\section{Palavras-chave}

Religiões Afro-brasileiras, Candomblé, Relações Raciais

\section{Introdução}

O Candomblé é uma religião que se universalizou nas últimas décadas, expandiu seu território de abrangência, diversificou seus adeptos e adaptou-se às mudanças pelas quais a sociedade brasileira passou. Em Campinas o Candomblé se constitui de maneira diferente de outras cidades, é majoritariamente branco e de Nação Angola, contrariando a tendência de outros lugares em que há predominância do Candomblé de Nação Ketu.

Tenho como referência as reflexões possíveis através da análise de Amaral e Silva (1993) sobre a diferença entre Candomblés de brancos e de negros, em que é notado que os considerados brancos teriam a possibilidade de ascender através de sua condição econômica e social prestigiosa, contornando assim a rígida hierarquia religiosa que e possível observar no Candomblé, gerando, dessa maneira, uma relação entre os adeptos brancos e negros marcada por uma desigualdade notável.

Assim, partindo da ideia de "raça" enquanto construto social que (con)figura relações sociais $e$, consequentemente, repensando a visão de "raça" como uma categoria que mobiliza discursos sobre bases biológicas e a existência de um caráter inato, assim como a ideia de uma democracia racial operante no páis, o trabalho se propõe a analisar as particularidades do Candomblé campineiro focando-se na "raça" de seus adeptos e investigando as possíveis reinvenções que esse indicador social possa ter acarretado no Candomblé campineiro.

\section{Resultados e Discussão}

Seguindo o mapeamento feito por Previtalli (2006), criou-se uma ideia do circuito social dos terreiros de Candomblé de Campinas e foi ele que guiou a escolha para os terreiros que serviriam de base de observação para os propósitos de investigação dessa pesquisa.

Foram realizadas entrevistas com os pais e mães de santo, assim como participação nos rituais públicos do Candomblé, os quais o povo de santo chama de festas ou toques. Em ambos foi possível observar as relações sociais entre os filhos de santo e entre esses e seus sacerdotes.

Os primeiros resultados obtidos de uma análise inicial são no sentido de observar que raça não pode ser pensada apartada de outros marcadores sociais. Nos estudos das relações raciais engendrados no Brasil, classicamente a ideia de raça é associada à classe, e os contatos entre negros e brancos são, no mais das vezes, pensados nessa chave analítica. Entretanto, no Candomblé é sugerido não só pelo trabalho de campo realizado para essa pesquisa, mas também corroborando o que outros autores já haviam assinalado, que além de classe, gênero também seria extremamente relevante para se pensar "raça" enquanto um indicador social na construção da ideia de "diferença" que opera nos terreiros de Candomblé de Campinas.

Paradoxalmente, também foi observada uma poderosa apropriação da ideia do que é ser negro e de uma África mítica por parte dos sacerdotes brancos que guia a legitimidade espiritual dos terreiros. A "reafricanização" exposta por autores como Reginaldo Prandi, Vagner Gonçalves e outros, desempenha papel fundamental sobre a concepção do que é ser negro e ser branco no Candomblé.

\section{Conclusões}

O Candomblé campineiro apresenta características únicas que o diferenciam de outros contextos. Tendo em vista outros contextos regionais, há um aumento sensível na participação de adeptos e sacerdotes brancos e mais ricos, o que se observa do circuito de terreiros é uma reelaboração das práticas, muito inspirada pela "reafricanização" em curso atualmente e que se apoia tremendamente em conhecimentos acadêmicos sobre o assunto a fim de legitimar práticas religiosas. Isto é, as relações entre negros e brancos no candomblé campineiro perpassam questões de gênero e classe, não somente de "raça". Assim complexifica-se a construção da diferença entre os adeptos.

\section{Agradecimentos}

Em primeiro lugar agradeço a todos os candomblecistas campineiros que contribuíram para a feitura dessa pesquisa. Agradeço ao Professor Doutor Christiano Key Tambascia pela inesgotável paciência durante toda orientação. Por fim, agradeço ao CNPq pelo fomento que tornou possível a condução dessa pesquisa.

AMARAL, Rita de Cássia e SILVA, Vagner Gonçalves da. A cor do axé: brancos e negros no candomblé de São Paulo. In: Estudos Afro-Asiáticos, n²5. São Paulo, 1993. PP 99-124

PREVITALli, Ivere Miranda. Candomblé: Agora é Angola. 2006. 148 páginas. Dissertação (Mestrado em Ciências Sociais) Pontifícia Universidade Católica de São Paulo, São Paulo, 2006. 